\title{
Synthesis of oseltamivir conjugates with lactose analogs for inhibition studies on Trypanosoma cruzi trans-sialidase
}

\author{
M. Eugenia Giorgi, Damian Piuselli, Rosalía Agusti, and Rosa M. de Lederkremer* \\ ${ }^{\dagger}$ CIHIDECAR, Departamento de Química Orgánica, Facultad de Ciencias Exactas y Naturales, \\ Universidad de Buenos Aires, Ciudad Universitaria, Pabellón II, 1428 Buenos Aires, Argentina \\ E-mail:lederk@go.fcen.uba.ar
}

\section{Dedicated to Professors Rita H. Rossi, Julio C. Podestá, Manuel González Sierra and Oscar S. Giordano}

\begin{abstract}
Trypanosoma cruzi, the agent of Chagas disease, expresses a unique enzyme, the trans-sialidase (TcTS) involved in the transfer of sialic acid from host glycoconjugates to mucins of the parasite. Crystallographic studies showed two sites in the catalytic region of TcTS, one binding the sialic acid donor and the other involved in binding terminal $\beta$-D-galactopyranosyl-containing compounds. We have previously described that lactose derivatives effectively inhibited the transfer of sialic acid to $N$-acetyllactosamine. On the other hand, oseltamivir is a sialic acid mimetic effective against some types of influenza virus. In this paper we report covalent conjugation of oseltamivir with lactose and lactobionolactone with the aim to obtain a bisubstrate potential inhibitor. The behavior of the new compounds in the TcTS reaction was studied.
\end{abstract}

Keywords: Trans-sialidase, oseltamivir, Trypanosoma cruzi, inhibitors, lactose derivatives

\section{Introduction}

Trypanosoma cruzi, the agent of American trypanosomiasis, ${ }^{1}$ expresses a unique enzyme, the trans-sialidase (TcTS), ${ }^{2}$ involved in the transfer of $\alpha(2,3)$-linked sialyl residues present in host sialoglycoconjugates to terminal D-galactopyranosyl units of mucins that are widely distributed on the parasite surface. ${ }^{3}$ This is the only way trypanosomes may incorporate sialic acid, instead of using the corresponding nucleotide sugar as donor. Sialylated mucins are in turn involved in the invasion of mammalian host cells and in the protection against lysis by serum factors. ${ }^{3}$ Oligosaccharides of the mucins have been synthesized and their acceptor and inhibitory properties were studied. $^{4,2 \mathrm{~d}}$ The TcTS is anchored to the membrane by 
glycosylphosphatidylinositol ${ }^{5}$ and is shed to the medium, then, it can be detected in the blood during the acute phase of the infection ${ }^{6}$ and may produce several abnormalities in the immune system. ${ }^{7}$ Also, in Trypanosoma brucei, the agent of sleeping sickness, incorporation of sialic acid through a trans-sialidase into the glycosylphosphatidylinositol anchor of the procyclin surface protein cover is essential for parasite survival in the tsetse fly. ${ }^{8}$ Trans-sialidase, being a virulence factor in the mammal and/or insect stages of trypanosomes and being specific for the parasite, with no equivalent in the human host, is an interesting target for drug design. The 3D structure of TcTS shows two catalytic sites in the active center: the sialic acid-binding site and the galactosebinding site. ${ }^{9}$ The TcTS works by a bisubstrate ping pong mechanism with formation of a covalent TcTS-sialosyl intermediate with Tyr 342, and acid-base catalysis. ${ }^{10}$ The active site of TcTS shows some conserved features of microbial sialidases including the presence of an arginine triad which interacts with the negatively charged carboxylate group of sialic acid. In the absence of a suitable carbohydrate acceptor, TcTS functions as a sialidase, catalyzing sialoside hydrolysis. ${ }^{11}$

Potential inhibitors for TcTS are usually classified depending on the active site region they target. In the last years several laboratories have been active in seeking inhibitors for TcTS, mainly directed to the sialic acid binding site. ${ }^{12}$ In particular, some natural products or synthetically modified natural products proved to be good inhibitors in vitro of the TcTS but the authors do not report studies on toxicity in animals. ${ }^{13}$ Inhibitors of TcTS directed to the $\beta$-galactosyl acceptor site should be more specific, as other sialidases lack this interaction. Lactose derivatives effectively inhibited the transfer of sialic acid to $N$-acetyllactosamine, lactitol being the best. ${ }^{14}$ The lactose analogs are only moderate inhibitors. However, they are non-toxic to animals. ${ }^{15}$ In fact, Mucci et al., proved that intravenous administration of $10 \mathrm{mg}$ of lactitol inhibited TcTS in mice blood by 95-98\%. Fast clearance from blood was solved using lactitol releasing pellets which prevented apoptosis of spleen cells. With the aim to improve the bioavailability lactose analogs have been conjugated with polyethylene glycol. ${ }^{16}$ Synthesis of a library of triazole substituted galactose derivatives and their evaluation against TcTs has been described. However, weak inhibition for TcTS-catalyzed hydrolysis of 2'-(4methylumbelliferyl)- $\alpha$-D- $N$-acetylneuraminic acid was observed. ${ }^{17}$

A good strategy to inhibit TcTS would involve compounds able to interact with both, the sialic acid and the $\beta$-galactopyranosyl binding sites. Following this direction Streicher and coworkers ${ }^{18}$ synthesized conjugates of carbocyclic sialyl mimetics with galactose.

2-Deoxy-2,3-didehydro-D- $N$-acetylneuraminic acid (DANA) a potent inhibitor of the homologous influenza neuraminidase is a very weak inhibitor of TcTS (Ki $12.3 \mathrm{mM}) .{ }^{19}$ Also, other transition-state analogue inhibitors such as zanamivir and BCX 1812 fail to inhibit TcTS at $1 \mathrm{mM}$ concentrations. ${ }^{12 a}$ However, DANA was the first compound which cocrystallized with TcTS and the acceptor lactose. ${ }^{20}$ Moreover, the Trypanosoma rangeli sialidase (TrSA) with $70 \%$ sequence identity with TcTS is efficiently inhibited by DANA $\left(K_{\mathrm{i}} 1.5 \mu \mathrm{M}\right) .{ }^{18}$ The sialyl transfer reaction of TcTS and the hydrolysis reaction of TrSA share the same mechanism up to the covalent intermediate with the sialyl substrate. ${ }^{21}$ Therefore, the different behavior of both 
enzymes towards inhibitors directed to the sialic acid binding site is not fully understood. Molecular dynamics simulations in the presence of ligands showed conformational changes in the catalytic cleft mainly due to the motion of residues W312 and Y119, in the lactose binding region of TcTS. ${ }^{22}$ Herein we describe another bi-substrate approach to target the donor and acceptor binding sites. Oseltamivir (1), an ester prodrug marketed as Tamiflu ${ }^{\mathrm{TM}}$ and a potent inhibitor of influenza virus neuraminidases ${ }^{23}$ was covalently conjugated to lactose analogs. The behavior of the compounds in the TcTS reaction was studied. Although sialyl mimetics such as zanamivir were no good inhibitors for TcTS, ${ }^{12 a}$ we hoped that the concomitant presence of a ligand to the acceptor site would provoke conformational changes favorable for TcTS inhibition.

\section{Results and Discussion}

Two different chemical approaches were used for conjugation of oseltamivir with disaccharide derivatives containing $\beta$-D-Gal $p$ as the reducing unit: 1 . Reductive amination of lactose with oseltamivir in the presence of $\mathrm{NaBH}_{3} \mathrm{CN}$ (Scheme 1). 2. Amide formation between the carboxyl group of lactobionic acid and the amino group of oseltamivir (Scheme 2).

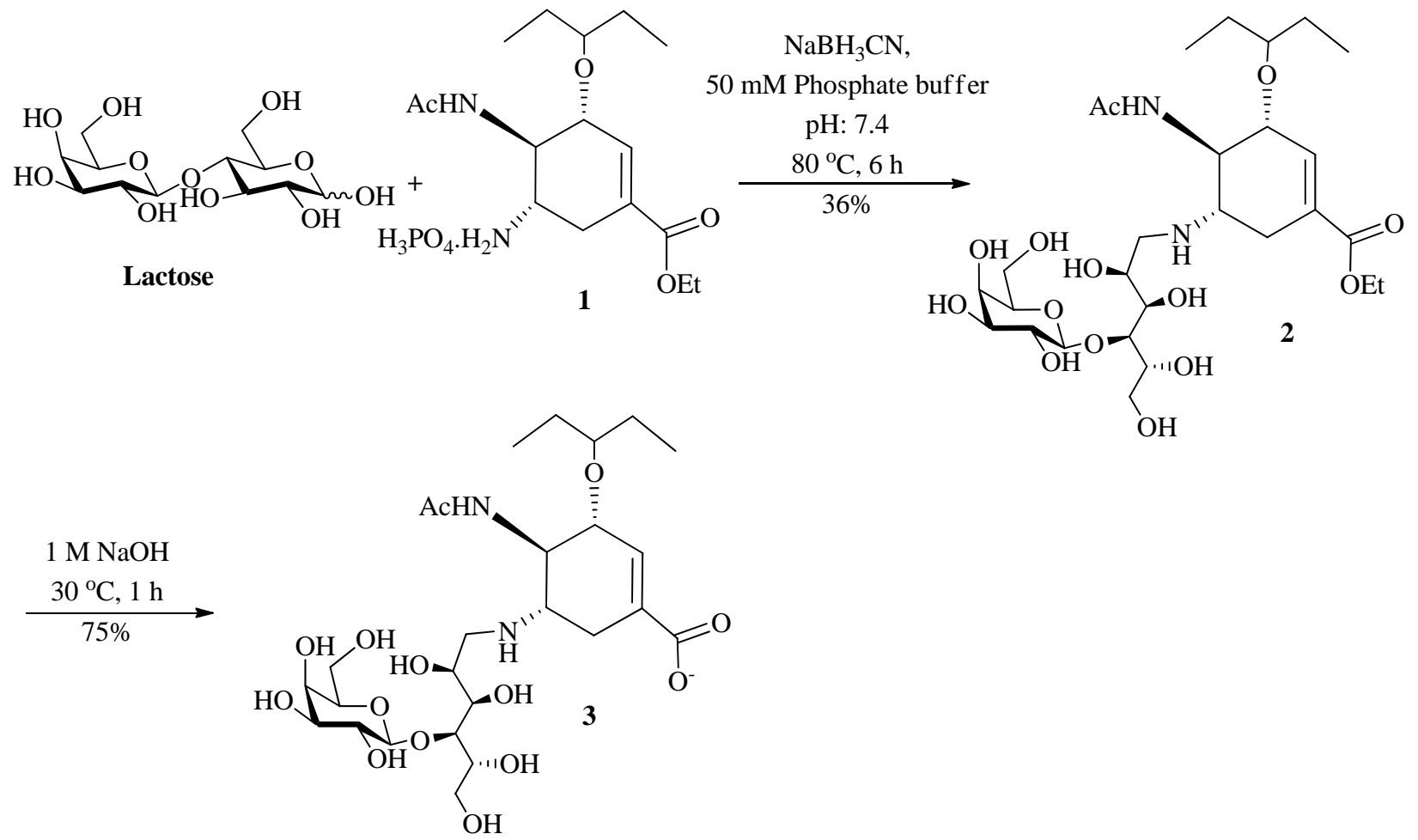

Scheme 1. Synthesis of compounds 2 and 3 from lactose.

In the first approach, the reaction monitored by TLC showed the appearance of a new compound with mobility in between lactose, which was revealed with the sulfuric acid reagent, and oseltamivir, which was only shown by exposing to UV light. After 6 h reaction the new 
compound 2, which was detected by both UV and the sulfuric acid reagent, was purified from the mixture by chromatography through a RP-18 cartridge and eluted with $50 \%$ methanol. Ethyl 4acetamido- $N$-(1'-deoxylactitol-1'-yl)-5-amino-3-(pentan-3-yloxy)-cyclohex-1-enecarboxylate 2 was obtained as a colorless amorphous solid in a moderate yield (36\%).

The NMR spectra showed the characteristic signals for the oseltamivir and sugar moieties. In the ${ }^{1} \mathrm{H}$ NMR spectrum the doublet for the only anomeric proton of the sugar at $\delta 4.49, J=8 \mathrm{~Hz}$, and the $\mathrm{H}-2$ at $\delta 6.8$ for the oseltamivir showed the same integration values. The 3-pentyl side chain gave two triplets for the methyl protons at $\delta 0.84$ and $\delta 0.89$ with $J=7.5 \mathrm{~Hz}$. Accordingly, the methylene protons appeared at different $\delta$. The new methylene amino protons appeared as two signals, a double doublet at $\delta 2.98$ with a geminal coupling constant of $12 \mathrm{~Hz}$ and $J_{1^{\prime}, 2^{\prime}}=2.5$ $\mathrm{Hz}$ and a triplet at $\delta 2.53, J=12 \mathrm{~Hz}$. As expected these methylene protons appeared upfield with respect to the oxymethylene protons of the sugar.

In the ${ }^{13} \mathrm{C}$ NMR spectrum the 3-pentyl side chain carbons of oseltamivir resonate at $\delta 8.7,8.9$ $\left(\mathrm{CH}_{3}\right), 25.3,25.7\left(\mathrm{CH}_{2}\right)$ and $84.2(\mathrm{CH}-\mathrm{O})$, the cyclohexene $\mathrm{C}-1$ and $\mathrm{C}-2$ appeared at $\delta 129.3$ and 138.3 and the carbons linked to nitrogen at $\delta 54.9$ and 55.7. In the sugar, the only anomeric carbon resonates at $\delta 103.1(\beta$-Gal $p)$ and the new formed $\mathrm{CH}_{2}-\mathrm{NH}$ signal of $\mathrm{C}-1$ ' appeared at $\delta$ 49.4. The HRMS gave $[\mathrm{M}+\mathrm{H}]^{+}$and $[\mathrm{M}+\mathrm{Na}]^{+}$values which confirmed the structure.

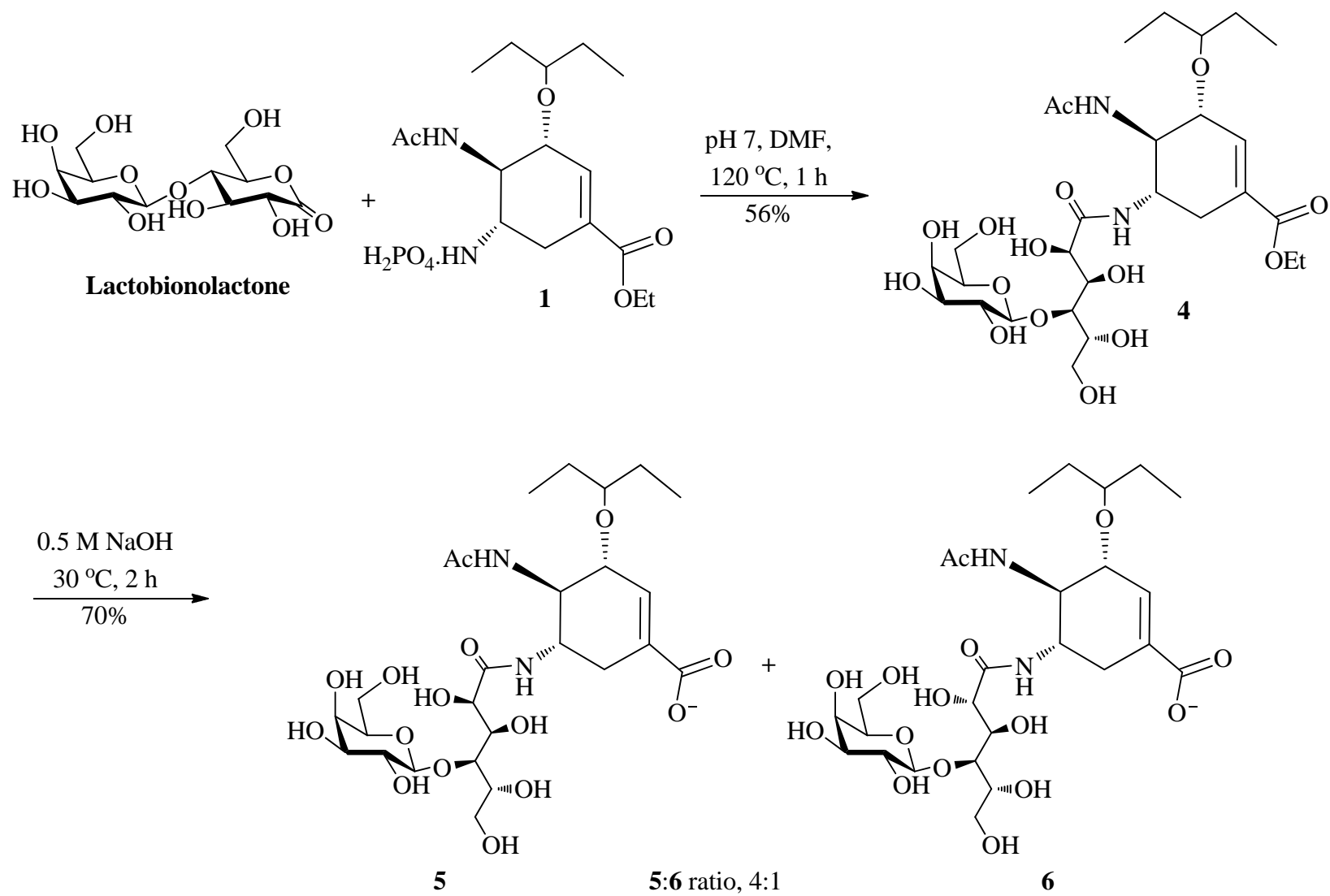

Scheme 2. Synthesis of compounds 4, 5 and $\mathbf{6}$ from lactobionolactone. 
Oseltamivir is marketed as the prodrug Tamiflu that after absorption is hydrolyzed by lipases to the corresponding carboxylic acid, which is the active form. In order to study its behavior as inhibitor in the trans-sialidase reaction we chemically hydrolyzed the ester to the carboxylate 3. After saponification of $\mathbf{2}$ for $1 \mathrm{~h}$ at $30^{\circ} \mathrm{C}$, TLC indicated formation of $\mathbf{3}$ with a lower mobility. The structure was confirmed by NMR analysis which showed complete disappearance of the $\mathrm{CH}_{3} \mathrm{CH}_{2}$ - signals corresponding to the ethyl ester.

For amidation, oseltamivir was heated with an excess of lactobionolactone till the drug was no longer detected by UV and the new compound $\mathbf{4}$ was shown by TLC with the sulfuric acid reagent (Scheme 2). The product was purified by passing through a RP-18 cartridge. Excess lactobionolactone was eluted with water whereas compound 4 was eluted with methanol and was obtained as an amorphous solid in 56\% yield. The structure was confirmed by NMR spectra. The signal for $\mathrm{H}-5$ of the oseltamivir moiety appeared at lower field in the amido conjugate 4 with respect to the amino conjugate 2 . In compound $4, \mathrm{H}-5$ could not be distinguished from the sugar protons in a complex region at $\delta 3.67-3.96$ whereas in $2 \mathrm{H}-5$ appeared at $\delta 2.94$. In the ${ }^{13} \mathrm{C} \mathrm{NMR}$ spectrum the new amide carbonyl appeared at $\delta 175.4$. By saponification of 4 the lactobionamideoseltamivir carboxylate 5 was obtained together with a minor compound which was tentatively assigned, on the basis of the ${ }^{1} \mathrm{H}$ NMR spectrum, to the C-2' epimeric compound $\mathbf{6}$ formed by the alkaline conditions and the presence of the carbonyl amide in the $\alpha$-position. The NMR spectra showed disappearance of the signals due to the ethyl ester and in the ${ }^{13} \mathrm{C}$ NMR spectrum the carbon of the carboxylic acid appeared at $\delta$ 169.6. In the ${ }^{1} \mathrm{H}$ NMR spectrum the anomeric proton (H-1'), H-2' and H-3', among others, appeared as double signals in a 4:1 ratio corresponding to both C-2' epimers. Also, H-2' and H-3' in 5 and $\mathbf{6}$ have different coupling constants confirming they were epimers. The presence of both compounds was confirmed by high performance anion exchange chromathography with pulse amperometric detection (HPAEC-PAD).

Studies on the behavior of the new oseltamivir conjugates as substrates and competitive inhibitors, in the trans-sialidase reaction, were performed using 3'-sialyllactose (3'SL) as donor and a recombinant TcTS (Scheme 3).

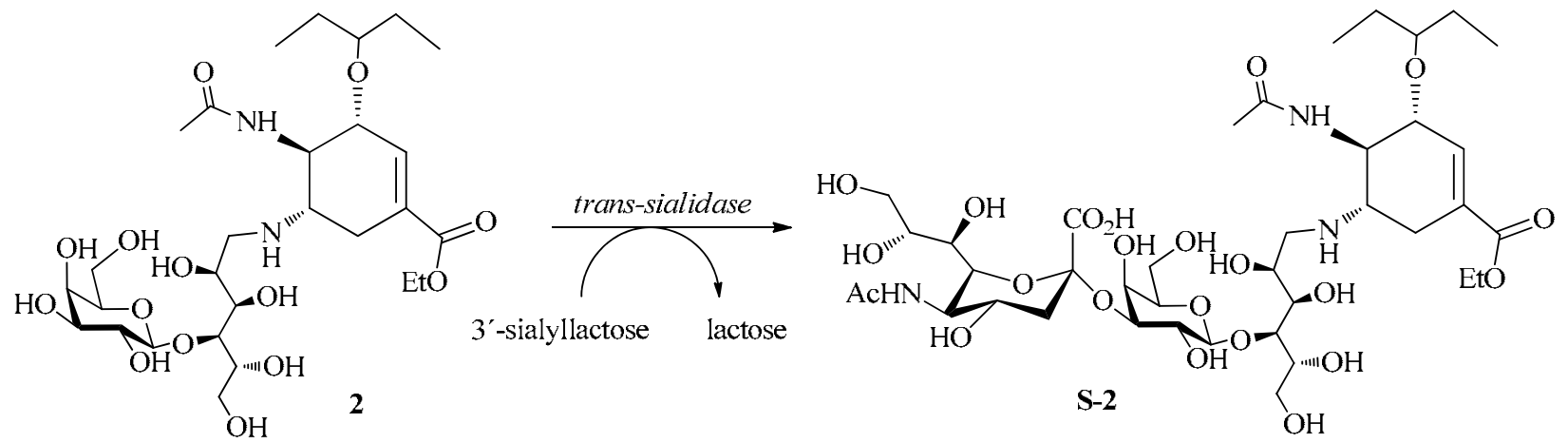

Scheme 3. Sialylation by TcTS of compound 2. 
The reactions were followed by HPAEC-PAD which showed that compound $\mathbf{6}$ incorporated sialic acid in the same extent as $\mathbf{5}$. For that reason, the kinetic determinations were performed using the mixture of $\mathbf{5}$ and $\mathbf{6}$. The retention times of the acceptor substrates and their sialylated products are shown in Table 1. The ethyl esters were not included in the table because they hydrolyzed during the alkaline conditions of the HPAEC and gave broad peaks.

Table 1. Retention times in HPAEC-PAD of compounds 3, 5, 6 and their sialylated products

\begin{tabular}{ccc}
\hline \multirow{2}{*}{ Compound } & \multicolumn{2}{c}{ Retention time (min) } \\
\cline { 2 - 3 } & Condition 1 & Condition 2 \\
\hline 3'-SL & 16.00 & - \\
$\mathbf{3}$ & 10.18 & - \\
S-3 & 25.4 & - \\
3'-SL & - & 11.33 \\
Lactobionic acid & - & 9.12 \\
S-Lactobionic & - & 25.72 \\
acid & - & 17.68 \\
$\mathbf{5}$ & - & 35.67 \\
S-5 & - & 15.15 \\
$\mathbf{6}$ & - & 33.70 \\
S-6 & - &
\end{tabular}

The conditions are specified in the Experimental section.

The ability of the conjugates to act as acceptor substrates in the TS reaction is expressed by the calculated $K_{\mathrm{m}}$ values which are compared with the values for lactitol and lactobionic acid (Table 2).

Table 2. Kinetic parameters for compounds 2-6 in the TcTS reaction

\begin{tabular}{ccc}
\hline Compound & $K \mathrm{~m}(\mathrm{mM})$ & $\mathrm{IC}_{50}(\mathrm{mM})$ \\
\hline Lactitol & 0.26 & 0.21 \\
$\mathbf{2}$ & 0.89 & 2.21 \\
$\mathbf{3}$ & 0.36 & 4.21 \\
Lactobionic acid & 0.19 & 0.33 \\
$\mathbf{4}$ & 0.30 & 4.26 \\
$\mathbf{5}$ and 6 (4:1) & 0.34 & 2.16 \\
Oseltamivir & & n.i. ${ }^{\mathrm{a}}$ \\
\hline
\end{tabular}

ano inhibition was observed at $2 \mathrm{mM}$ concentration. 
All the compounds were acceptors for sialic acid with $K_{\mathrm{m}}$ values in the range of lactitol. Inhibition of sialylation of the substrate $N$-acetyllactosamine by the synthetic compounds was also studied. The $\mathrm{IC}_{50}$ values were one order higher than for the non-conjugated products. The results indicate that conjugation with oseltamivir does not affect interaction of the acceptor with the sugar binding site although, as shown for the free drug, is not effective for displacement of the sialic acid donor. The new oseltamivir sugar derivatives could be used to test them as inhibitors of the influenza virus neuraminidases. In this respect galactose-conjugates of oseltamivir have been prepared as tools for the characterization of influenza neuraminidases. ${ }^{24}$

\section{Experimental Section}

General. Lactobionic acid, lactose and $N$-acetyllactosamine were purchased from Sigma Chemical Co. 3'-sialyllactose was obtained form bovine colostrum by an adaptation of a reported

method. ${ }^{25}$ Optical rotations were measured with a Perkin-Elmer 343 polarimeter. NMR spectra were recorded with a Bruker AM 500 spectrometer at $500 \mathrm{MHz}\left({ }^{1} \mathrm{H}\right)$ and $125 \mathrm{MHz}\left({ }^{13} \mathrm{C}\right)$ at $30{ }^{\circ} \mathrm{C}$. Assignments were supported by 2D HSQC and 2D COSY experiments. High resolution electrospray ionization mass spectra (ESI-TOF) were recorded on BRUKER microTOF-Q II ESIQq-TOF spectrometer. Analytical TLC was performed on $0.2 \mathrm{~mm}$ Silica Gel $60 \mathrm{~F}_{254}$ (Merck) aluminium supported plates. Detection was effected by exposure to UV light or by spraying with $10 \%(\mathrm{v} / \mathrm{v})$ sulfuric acid in ethanol containing $0.5 \%$ p-anisaldehyde and charring. Reverse phase column chromatography was performed on RP-18 cartridges (Strata, Phenomenex). For the sialylation experiments a recombinant TcTS expressed in Escherichia coli was kindly provided by A. C. C. Frasch (UNSAM, General San Martín, Buenos Aires, Argentina)

Analysis by HPAEC-PAD was performed using a Dionex ICS 3000 HPLC system equipped with a pulse amperometric detector. A CarboPac PA-100 ion exchange analytical column $(4 \times 250$ $\mathrm{mm})$ equipped with a guard column PA-100 (4 $\times 50 \mathrm{~mm})$ was used under the following conditions:

Condition 1: Linear gradient over 60 min from 30 to $300 \mathrm{mM} \mathrm{NaOAc}$ in $100 \mathrm{mM} \mathrm{NaOH}$ at a flow rate of $0.9 \mathrm{ml} / \mathrm{min}$ at $25{ }^{\circ} \mathrm{C}$.

Condition 2: Linear gradient over $15 \mathrm{~min}$ from 30 to $100 \mathrm{mM} \mathrm{NaOAc}$ in $100 \mathrm{mM} \mathrm{NaOH}$ followed by a linear gradient over 30 min from 100 to $350 \mathrm{mM} \mathrm{NaOAc}$ in $100 \mathrm{mM} \mathrm{NaOH}$ at a flow rate of $0.9 \mathrm{ml} / \mathrm{min}$ at $25{ }^{\circ} \mathrm{C}$.

\section{Enzyme kinetics}

Reaction mixtures of $20 \mu \mathrm{l}$ containing $20 \mathrm{mM}$ Tris-HCl, pH 7 buffer, $30 \mathrm{mM} \mathrm{NaCl,} 1 \mathrm{mM}$ 3'sialyllactose as donor, and compounds 2-5 as acceptor substrates were incubated with $300 \mathrm{ng}$ purified TcTS for $15 \mathrm{~min}$ at room temperature. Samples were then diluted 12 times with deionized water and analyzed by HPAEC-PAD. For $K_{\mathrm{m}}$ calculations a set of 6 points ranging from 0 to $1 \mathrm{mM}$ of each compound was used. Each incubation was performed at least in 
duplicate. D-Galacturonic acid was used as internal standard for compounds $\mathbf{2}$ and $\mathbf{3}$ and DGlycolylneuraminic acid for compounds 4 and 5. The extent of sialylation was calculated by integration of the corresponding sialylated products. The $K_{\mathrm{m}}$ values were determined using the Lineweaver-Burk method.

\section{Inhibition of sialylation of $N$-acetyllactosamine}

Reaction mixtures of $20 \mu \mathrm{l}$ containing $20 \mathrm{mM}$ Tris-HCl, pH 7 buffer, $30 \mathrm{mM} \mathrm{NaCl}, 1 \mathrm{mM}$ 3'sialyllactose as donor, $1 \mathrm{mM} \mathrm{N}$-acetyl-lactosamine, and different concentrations of compounds 25 were incubated with $300 \mathrm{ng}$ purified TcTS for $15 \mathrm{~min}$ at room temperature. Samples were then diluted 12 times with deionized water and analyzed by HPAEC-PAD. Inhibition was calculated from the amount of 3'-sialyl- $N$-acetyl-lactosamine with respect to the total amount of sialylated compounds obtained with or without inhibitor. The $\mathrm{IC}_{50}$ values indicate the concentration of inhibitor required to give $50 \%$ inhibition under the assay conditions.

\section{$(3 R, 4 R, 5 S)$ Ethyl 4-acetamido- $N$-(1'-deoxylactitol-1'-yl)-5-amino-3-(pentan-3-yloxy)-} cyclohex-1-enecarboxylate (2). Lactose (170 $\mathrm{mg}, 0.5 \mathrm{mmol})$ and oseltamivir phosphate (1, 100 $\mathrm{mg}, 0.25 \mathrm{mmol}$ ) were dissolved in phosphate buffer ( $\mathrm{pH}$ 7.4). After $1 \mathrm{~h}$ of stirring at room temperature, $\mathrm{NaBH}_{3} \mathrm{CN}$ (50 mg, $0.8 \mathrm{mmol}$ ) was added and the reaction was kept at $80{ }^{\circ} \mathrm{C}$ for $6 \mathrm{~h}$. TLC $\left(\mathrm{EtOH} / \mathrm{H}_{2} \mathrm{O} / 28 \% \mathrm{NH}_{3}, 18: 3: 1.5\right)$ showed the appearance of a new compound, $\mathrm{R}_{f} 0.5$, between lactose $\left(\mathrm{R}_{f} 0.2\right)$ and oseltamivir $\left(\mathrm{R}_{f} 0.72\right)$. The latter compound was only detected by exposing to UV light whereas the conjugate was detected with both, UV and the sulfuric acid reagent. The reaction mixture was evaporated in vacuum, boric acid was removed by successive coevaporations with methanol and the product was purified by passage through a RP-18 column (5 g). Excess of lactose was eluted with water and then a gradient from 10 to $60 \%$ methanol was passed through the column. Compound 2 was eluted with $50 \%$ methanol and after evaporation a colorless solid was obtained (116 mg, 36\%). [ $\alpha]_{\mathrm{D}}-23$ (c 0.6, $\mathrm{H}_{2} \mathrm{O}$ ). ${ }^{1} \mathrm{H}$ NMR $\left(\mathrm{D}_{2} \mathrm{O}\right) \delta 6.80$ (br s, 1H, H-2), 4.49 (d, 1H, $J_{1 ", 2}$ " $=8 \mathrm{~Hz}, \mathrm{H}-1$ "), 4.24 (m, 3H, H-3 and $\mathrm{CH}_{3} \mathrm{CH}_{2} \mathrm{OCO}$ ), 4.00 (m, 1H, H2'), 3.96-3.67 (m, 10H, sugar protons and $\mathrm{H}-4$ of the oseltamivir moiety), 3.65 (dd, $1 \mathrm{H}, J_{2^{\prime \prime}, 3^{\prime \prime}}=10$ $\mathrm{Hz}, J_{3^{\prime \prime}, 4}=3.5 \mathrm{~Hz}, \mathrm{H}-3$ ”), 3.53 (dd, $1 \mathrm{H}, J=10 \mathrm{~Hz}, 8 \mathrm{~Hz}, \mathrm{H}-2$ "), 3.53-3.48 (m, $1 \mathrm{H}, \mathrm{CH}_{3} \mathrm{CH}_{2} \mathrm{CH}$ of the 3-pentyl moiety), 2.98 (dd, $\left.1 \mathrm{H}, J_{1^{\prime} \mathrm{a}, 1^{\prime} \mathrm{b}}=12 \mathrm{~Hz}, J_{1^{\prime} \mathrm{a}, 2^{\prime}}=2.5 \mathrm{~Hz}, \mathrm{H}-1^{\prime} \mathrm{a}\right), 2.94$ (m, 1H, H-5), 2.85 (dd, $\left.1 \mathrm{H}, J_{6 \mathrm{a}, 6 \mathrm{~b}}=17 \mathrm{~Hz}, J_{5,6 \mathrm{a}}=5 \mathrm{~Hz}, \mathrm{H}-6 \mathrm{a}\right), 2.53$ (dd, $1 \mathrm{H}, J=12 \mathrm{~Hz}, J_{1^{\prime} \mathrm{b}, 2^{\prime}}=11 \mathrm{~Hz}, \mathrm{H}-1^{\prime}$ b), 2.15 (m, $1 \mathrm{H}, \mathrm{H}-6 \mathrm{~b}), 2.07$ (s, 3H, $\left.\mathrm{CH}_{3} \mathrm{CONH}\right), 1.55\left(\mathrm{~m}, 3 \mathrm{H},\left(\mathrm{CH}_{3} \mathrm{CH}_{2} \mathrm{CH}\right)_{\mathrm{x}}\right.$ and $\left(\mathrm{CH}_{3} \mathrm{CH} \mathrm{H}_{2 \mathrm{a}} \mathrm{CH}\right)_{\mathrm{y}}$ of the 3-pentyl moiety), $1.45\left(\mathrm{~m}, 1 \mathrm{H},\left(\mathrm{CH}_{3} \mathrm{CH}_{2 \mathrm{~b}} \mathrm{CH}\right)_{\mathrm{y}}\right.$ of the 3-pentyl moiety), 1.29 (t, 3H, $J=7.5$ $\mathrm{Hz}, \mathrm{CH}_{3} \mathrm{CH}_{2} \mathrm{OCO}$ ), 0.89 (t, $3 \mathrm{H}, J=7.5 \mathrm{~Hz},\left(\mathrm{CH}_{3} \mathrm{CH}_{2} \mathrm{CH}\right)_{\mathrm{x}}$ of the 3-pentyl moiety), 0.84 (t, $3 \mathrm{H}, J$ $=7.5 \mathrm{~Hz},\left(\mathrm{CH}_{3} \mathrm{CH}_{2} \mathrm{CH}\right)_{\mathrm{y}}$ of the 3-pentyl moiety). ${ }^{13} \mathrm{C}$ NMR $\left(\mathrm{D}_{2} \mathrm{O}\right) \delta 174.9\left(\mathrm{CH}_{3} \mathrm{CONH}\right), 167.3$ ( $\mathrm{CH}_{3} \mathrm{CH}_{2} \mathrm{OCO}$ ), 138.3 (C-2), 129.3 (C-1), 103.1 (C-1"), $84.4\left(\mathrm{CH}_{3} \mathrm{CH}_{2} \mathrm{CH}\right.$ of the 3-pentyl moiety), 76.4 (C-3), 72.8 (C-3”), 71.4 (C-2”), 71.2 (C-3'), 70.9 (C-2'), $62.5\left(\mathrm{CH}_{3} \mathrm{CH}_{2} \mathrm{OCO}\right), 62.4$ and 61.3 (C-6' and C-6”), 55.8 (C-5), 55 (C-4), 49.4 (C-1'), 29.3 (C-6), $25.7\left(\left(\mathrm{CH}_{3} \mathrm{CH}_{2} \mathrm{CH}\right)_{\mathrm{x}}\right.$ of the 3-pentyl moiety), $25.3\left(\left(\mathrm{CH}_{3} \mathrm{CH}_{2} \mathrm{CH}\right)_{\mathrm{y}}\right.$ of the 3-pentyl moiety), $22.6\left(\mathrm{CH}_{3} \mathrm{CONH}\right), 13.9$ $\left(\mathrm{CH}_{3} \mathrm{CH}_{2} \mathrm{OCO}\right), 8.9\left(\left(\mathrm{CH}_{3} \mathrm{CH}_{2} \mathrm{CH}\right)_{\mathrm{x}}\right.$ of the 3-pentyl moiety), $8.7\left(\left(\mathrm{CH}_{3} \mathrm{CH}_{2} \mathrm{CH}\right)_{\mathrm{y}}\right.$ of the 3-pentyl 
moiety), 79.2, 75.7, 71.4 and 69 (C-4', C-5', C-4” and C-5”). ESI-TOF MS $\mathrm{m} / \mathrm{z}$ : calcd for $[\mathrm{M}+\mathrm{H}]^{+}:$639. 3340, found: 639.3350. Calcd for $[\mathrm{M}+\mathrm{Na}]^{+}:$661.3160, found 661.3170.

$(3 R, 4 R, 5 S)$ 4-acetamido- $N$-(1'-deoxylactitol-1'-yl)-5-amino-3-(pentan-3-yloxy)-cyclohex-1enecarboxylic acid (3). Compound 2 (28 mg) was dissolved in $1 \mathrm{M} \mathrm{NaOH}(1 \mathrm{~mL})$ and stirred for $1 \mathrm{~h}$ at $30^{\circ} \mathrm{C}$. The reaction was monitored by TLC which showed hydrolysis of compound 2 with the formation of the carboxylic acid 3, $R_{f} 0.32$ (EtOH: $\left.\mathrm{H}_{2} \mathrm{O}: 28 \% \mathrm{NH}_{3}, 18: 3: 1.5\right)$. The product was purified by passage through the cationic resin AG50W-X12 (Bio-Rad). After washing with water, the product was eluted with $0.1 \mathrm{M} \mathrm{HCl}$. Lyophilization afforded $20 \mathrm{mg}$ (75\%) of compound 3 as a colorless amorphous solid. [ $\alpha]_{\mathrm{D}}-20$ (c 0.6, $\left.\mathrm{H}_{2} \mathrm{O}\right) .{ }^{1} \mathrm{H}$ NMR $\left(\mathrm{D}_{2} \mathrm{O}\right) \delta 6.87$ (br s, $\left.1 \mathrm{H}, \mathrm{H}-2\right), 4.54$ (d, $1 \mathrm{H}, J_{1,2},{ }^{\prime}=8 \mathrm{~Hz}, \mathrm{H}-1$ "), 4.35 (dd, $1 \mathrm{H}, J_{3,4}=9 \mathrm{~Hz}, J_{3,2}<1 \mathrm{~Hz}, \mathrm{H}-3$ ), 4.2 (m, 1H, H-2'), 4.16 (dd, $\left.1 \mathrm{H}, J=9 \mathrm{~Hz}, J_{4,5}=12 \mathrm{~Hz}, \mathrm{H}-4\right), 3.95-3.68(\mathrm{~m}, 10 \mathrm{H}$, sugar protons and $\mathrm{H}-5$ of the oseltamivir moiety), 3.66 (dd, $1 \mathrm{H}, J_{2^{\prime \prime}, 3^{\prime \prime}}=10 \mathrm{~Hz}, J_{3^{\prime \prime}, 4}=3.5 \mathrm{~Hz}, \mathrm{H}-3$ ”), 3.55 (dd, $1 \mathrm{H}, J=8 \mathrm{~Hz}, 10$ $\mathrm{Hz}, \mathrm{H}-2$ "), 3.55 (m, $1 \mathrm{H}, \mathrm{CH}_{3} \mathrm{CH}_{2} \mathrm{CH}$ of the 3-pentyl moiety), 3.49 (dd, $1 \mathrm{H}, J_{1}{ }^{\prime} \mathrm{a}, 1^{\prime} \mathrm{b}=13 \mathrm{~Hz}, J_{1^{\prime} \mathrm{a}, 2}=$ $3.5 \mathrm{~Hz}, \mathrm{H}-1^{\prime}$ 'a), 3.21 (dd,1H, $J=13 \mathrm{~Hz}, J_{1^{\prime} \mathrm{b}, 2^{\prime}}=8.5 \mathrm{~Hz}, \mathrm{H}-1^{\prime} \mathrm{b}$ ), 3.01 (dd, $1 \mathrm{H}, J_{6 \mathrm{a}, 6 \mathrm{~b}}=17 \mathrm{~Hz}, J_{5,6 \mathrm{a}}$ $=5.5 \mathrm{~Hz}, \mathrm{H}-6 \mathrm{a}), 2.6(\mathrm{~m}, 1 \mathrm{H}, \mathrm{H}-6 \mathrm{~b}), 2.1\left(\mathrm{~s}, 3 \mathrm{H}, \mathrm{CH}_{3} \mathrm{CONH}\right), 1.57\left(\mathrm{~m}, 3 \mathrm{H},\left(\mathrm{CH}_{3} \mathrm{CH}_{2} \mathrm{CH}\right)_{\mathrm{x}}\right.$ and $\left(\mathrm{CH}_{3} \mathrm{CH}_{2 a} \mathrm{CH}\right)_{\mathrm{y}}$ of the 3-pentyl moiety), $1.47\left(\mathrm{~m}, 1 \mathrm{H},\left(\mathrm{CH}_{3} \mathrm{CH}_{2 \mathrm{~b}} \mathrm{CH}\right)_{\mathrm{y}}\right.$ of the 3-pentyl moiety), 0.88 (t, $3 \mathrm{H}, J=7.5 \mathrm{~Hz},\left(\mathrm{CH}_{3} \mathrm{CH}_{2} \mathrm{CH}\right)_{\mathrm{x}}$ of the 3-pentyl moiety), $0.84(\mathrm{t}, 3 \mathrm{H}, J=7.5 \mathrm{~Hz}$, $\left(\mathrm{CH}_{3} \mathrm{CH}_{2} \mathrm{CH}\right)_{y}$ of the 3-pentyl moiety). ${ }^{13} \mathrm{C}$ NMR $\left(\mathrm{D}_{2} \mathrm{O}\right) \delta 175.3\left(\mathrm{CH}_{3} \mathrm{CONH}\right), 169.3\left(\mathrm{CO}_{2} \mathrm{H}\right)$, 137.6 (C-2), 127.8 (C-1), 102.9 (C-1"), $84.3\left(\mathrm{CH}_{3} \mathrm{CH}_{2} \mathrm{CH}\right.$ of the 3-pentyl moiety), 75.1 (C-3), 72.4 (C-3”), 70.9 (C-2”), 70.8 (C-3'), 79.0 (C-4'), 75.4 (C-5”), 70.9 and 68.6 (C-4” and C-5'), 67.7 (C-2'), 61.8 and 61.2 (C-6' and C-6”), 55.6 (C-5), 51.6 (C-4), 48.0 (C-1'), 26.1 (C-6), 25.4 $\left(\left(\mathrm{CH}_{3} \mathrm{CH}_{2} \mathrm{CH}\right)_{\mathrm{x}}\right.$ of the 3-pentyl moiety), $25.0\left(\left(\mathrm{CH}_{3} \mathrm{CH}_{2} \mathrm{CH}\right)_{\mathrm{y}}\right.$ of the 3-pentyl moiety), 22.4 $\left(\mathrm{CH}_{3} \mathrm{CONH}\right), 8.5\left(\left(\mathrm{CH}_{3} \mathrm{CH}_{2} \mathrm{CH}\right)_{x}\right.$ and $\left(\mathrm{CH}_{3} \mathrm{CH}_{2} \mathrm{CH}\right)_{y}$ of the 3-pentyl moiety).

$(3 R, 4 R, 5 S)$ Ethyl 4-acetamido-5-lactobionamido-3-(pentan-3-yloxy)-cyclohex-1-enecarboxylate (4). Lactobionolactone was prepared from lactobionic acid as previously described. $^{26}$ Analysis by TLC showed disappearance of lactobionic acid, $R_{f} \quad 0.78$ $\left(\mathrm{EtOH} / \mathrm{H}_{2} \mathrm{O} / \mathrm{AcOH}, 12: 5: 3\right)$ IR $(\mathrm{C}=\mathrm{O}) 1741 \mathrm{~cm}^{-1}$.

Lactobionolactone (200 mg, $0.59 \mathrm{mmol})$ and oseltamivir phosphate $(123 \mathrm{mg}, 0.3 \mathrm{mmol})$ were dissolved in anhydrous dimethylformamide $(1.5 \mathrm{~mL})$ under argon and anhydrous pyridine was added to $\mathrm{pH}$ 7. The reaction mixture was heated at $120{ }^{\circ} \mathrm{C}$ and monitored by TLC $\left(\mathrm{nBuOH} / \mathrm{H}_{2} \mathrm{O} / \mathrm{AcOH}, 12: 5: 3\right)$. After $6 \mathrm{~h}$, oseltamivir was not longer detected by UV and compound $\mathbf{4}$ was shown with the sulfuric acid reagent $\left(R_{f} 0.5\right)$.

After evaporation the product was purified by passing through an RP-18 cartridge. Excess lactobionolactone was eluted with methanol. Evaporation of the solvent yielded compound $\mathbf{4}$ as a colorless amorphous solid (110 mg, 56\%). $[\alpha]_{\mathrm{D}}-35\left(\mathrm{c} 1, \mathrm{H}_{2} \mathrm{O}\right) .{ }^{1} \mathrm{H}$ NMR $\left(\mathrm{D}_{2} \mathrm{O}\right) \delta 6.8$ (br s, $1 \mathrm{H}, \mathrm{H}-$ 2), 4.55 (d, $1 \mathrm{H}, J_{1^{\prime}, 2^{\prime}}=7.5 \mathrm{~Hz}, \mathrm{H}-1$ ”), 4.4 (d, $1 \mathrm{H}, J_{2^{\prime}, 3}$, $2.5 \mathrm{~Hz}, \mathrm{H}-2^{\prime}$ ), 4.33 (dd, $1 \mathrm{H}, J_{3,4}=9 \mathrm{~Hz}$, $J_{3,2}<1 \mathrm{~Hz}, \mathrm{H}-3$ ), 4.23 (dq, 2H, $J=7 \mathrm{~Hz}, 1.6 \mathrm{~Hz}, \mathrm{CH}_{3} \mathrm{CH}_{2} \mathrm{OCO}$ ), 4.16 (dd, $1 \mathrm{H}, J=2.5 \mathrm{~Hz}, J_{3^{\prime}, 4^{\prime}}=$ 4 Hz, H-3'), 4.15 (m, 1H, H-5), 3.99-3.89 (m, 4H, H-4,H-4', H-4”' and H-5'), 3.86 (dd, 1H, $J_{6}^{\prime}$ a,6’b $=12 \mathrm{~Hz}, J_{6}{ }^{\prime} \mathrm{a}, 5=3.5 \mathrm{~Hz}, \mathrm{H}-6$ 'a), 3.81-3.7 (m, 4H, H-6”a, H-6”b, H-5” and H-6’b), 3.66 (dd, $1 \mathrm{H}$, $J_{2^{\prime \prime}, 3^{\prime \prime}}=10 \mathrm{~Hz}, J_{3^{\prime \prime}, 4^{\prime \prime}}=3.5 \mathrm{~Hz}, \mathrm{H}-3$ ”), 3.55 (dd, $1 \mathrm{H}, J=7.5 \mathrm{~Hz}, 10 \mathrm{~Hz}, \mathrm{H}-2$ "), 3.51 (m, $1 \mathrm{H}$, 
$\mathrm{CH}_{3} \mathrm{CH}_{2} \mathrm{CH}$ of the 3-pentyl moiety), 2.75 (dd, $\left.1 \mathrm{H}, J_{6 \mathrm{a}, 6 \mathrm{~b}}=17 \mathrm{~Hz}, J_{5,6 \mathrm{a}}=5.5 \mathrm{~Hz}, \mathrm{H}-6 \mathrm{a}\right), 2.42$ (m, $1 \mathrm{H}, \mathrm{H}-6 \mathrm{~b}), 1.99$ (s, 3H, $\left.\mathrm{CH}_{3} \mathrm{CONH}\right), 1.55\left(\mathrm{~m}, 3 \mathrm{H},\left(\mathrm{CH}_{3} \mathrm{CH}_{2} \mathrm{CH}\right)_{\mathrm{x}}\right.$ and $\left(\mathrm{CH}_{3} \mathrm{CH}_{2 \mathrm{a}} \mathrm{CH}\right)_{\mathrm{y}}$ of the 3pentyl moiety), $1.45\left(\mathrm{~m}, 1 \mathrm{H},\left(\mathrm{CH}_{3} \mathrm{CH}_{2 \mathrm{~b}} \mathrm{CH}\right)_{\mathrm{y}}\right.$ of the 3-pentyl moiety), 1.28 (t, $3 \mathrm{H}, J=7 \mathrm{~Hz}$, $\mathrm{CH}_{3} \mathrm{CH}_{2} \mathrm{OCO}$ ), 0.89 (t, 3H, $J=7.5 \mathrm{~Hz},\left(\mathrm{CH}_{3} \mathrm{CH}_{2} \mathrm{CH}\right)_{\mathrm{x}}$ of the 3-pentyl moiety), 0.83 (t, $3 \mathrm{H}, J=$ $7.5 \mathrm{~Hz},\left(\mathrm{CH}_{3} \mathrm{CH}_{2} \mathrm{CH}\right)_{\mathrm{y}}$ of the 3-pentyl moiety). ${ }^{13} \mathrm{C}$ NMR $\left(\mathrm{D}_{2} \mathrm{O}\right) \delta 175.4$ (C-1'), 174.9 $\left(\mathrm{CH}_{3} \mathrm{CONH}\right), 168.7\left(\mathrm{CH}_{3} \mathrm{CH}_{2} \mathrm{OCO}\right), 138.6$ (C-2), 129.9 (C-1), 104.2 (C-1"), $84.0\left(\mathrm{CH}_{3} \mathrm{CH}_{2} \mathrm{CH}\right.$ of the 3-pentyl moiety), 81.7 (C-4’), 76.7 (C-3), 76.0 (C-5”), 73.1 (C-3”), 73.0 (C-2'), 71.7 (C-2”), 70.8 (C-3'), 72.0 and 69.3 (C-4” and C-5'), 62.8 ( $\left.\mathrm{CH}_{3} \mathrm{CH}_{2} \mathrm{OCO}\right), 62.6$ and 61.7 (C-6' and C-6”), 54.6 (C-4), 48.2 (C-5), 30.7 (C-6), $26.2\left(\left(\mathrm{CH}_{3} \mathrm{CH}_{2} \mathrm{CH}\right)_{\mathrm{x}}\right.$ of the 3-pentyl moiety), 25.8 $\left(\left(\mathrm{CH}_{3} \mathrm{CH}_{2} \mathrm{CH}\right)_{y}\right.$ of the 3-pentyl moiety), $22.9\left(\mathrm{CH}_{3} \mathrm{CONH}\right), 13.9\left(\mathrm{CH}_{3} \mathrm{CH}_{2} \mathrm{OCO}\right), 9.2$ $\left(\mathrm{CH}_{3} \mathrm{CH}_{2} \mathrm{CH}\right.$ of the 3-pentyl moiety). ESI-TOF MS $\mathrm{m} / \mathrm{z}$ : calcd for $[\mathrm{M}+\mathrm{H}]^{+}: 653.3133$, found: 653.3149 .

(3R, 4R, 5S) 4-acetamido-5-lactobionamido-3-(pentan-3-yloxy)-cyclohex-1-ene-carboxylic acid (5) and C-2'epimeric compound (6). Compound 4 (30 mg) was dissolved in $0.5 \mathrm{M} \mathrm{NaOH}$ $(1 \mathrm{~mL})$ and stirred for $2 \mathrm{~h}$ at $30^{\circ} \mathrm{C}$. TLC showed complete hydrolysis to afford compounds 5 and 6, $R_{f} 0.4\left(\mathrm{nBuOH} / \mathrm{H}_{2} \mathrm{O} / \mathrm{AcOH}, 12: 5: 3\right)$. The product was purified by passage through a cationic resin and eluted with water to yield $21 \mathrm{mg}(70 \%)$ of 5 and 6 as a 8:2 epimeric mixture. $[\alpha]_{\mathrm{D}}-39$ (c 0.5, $\mathrm{H}_{2} \mathrm{O}$ ). ${ }^{1} \mathrm{H}$ NMR $\left(\mathrm{D}_{2} \mathrm{O}\right) \delta 6.81$ (br s, $\left.1 \mathrm{H}, \mathrm{H}-2\right), 4.54$ (d, 0.2H, $J_{1}$, ${ }_{2}$, $=7.8 \mathrm{~Hz}, \mathrm{H}-1$ ” for 6 ), 4.53

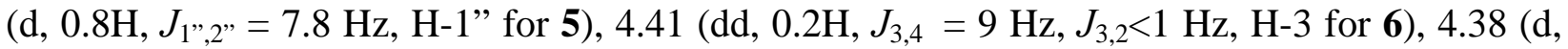
$0.8 \mathrm{H}, J_{2^{\prime}, 3^{\prime}}=2.6 \mathrm{~Hz}, \mathrm{H}-2^{\prime}$ ' for 5), 4.36 (d, $0.2 \mathrm{H}, J_{2^{\prime}, 3^{\prime}}=1.9 \mathrm{~Hz}, \mathrm{H}-2^{\prime}$ ' for 6), 4.31 (dd, $0.8 \mathrm{H}, J_{3,4}=9$ $\mathrm{Hz}, J_{3,2}<1 \mathrm{~Hz}, \mathrm{H}-3$ for 5), 4.20 (dd, $0.2 \mathrm{H}, J=1.9 \mathrm{~Hz}, J_{3^{\prime}, 4^{\prime}}=4 \mathrm{~Hz}, \mathrm{H}-3$ ' for 6), 4.15 (dd, $0.8 \mathrm{H}, J=$ $2.6 \mathrm{~Hz}, J_{3}{ }^{\prime},{ }^{\prime}=4 \mathrm{~Hz}, \mathrm{H}-3$ ' for 5), 4.14 (m, 1H, H-5), 3.99-3.92 (m, 2H, H-4 and H-4'), 3.92-3.87

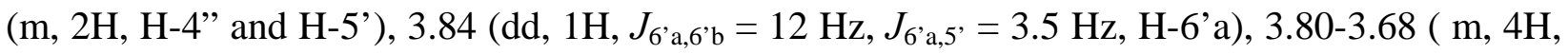

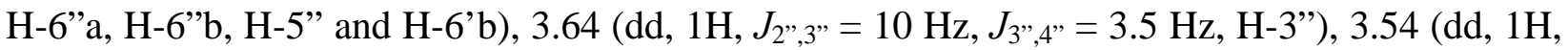
$J=7.8 \mathrm{~Hz}, 10 \mathrm{~Hz}, \mathrm{H}-2$ ”), 3.51 (m, $1 \mathrm{H}, \mathrm{CH}_{3} \mathrm{CH}_{2} \mathrm{CH}$ of the 3-pentyl moiety), 2.7 (dd, $1 \mathrm{H}, J_{6 \mathrm{a}, 6 \mathrm{~b}}=$ $\left.17.5 \mathrm{~Hz}, J_{5,6 \mathrm{a}}=5.5 \mathrm{~Hz}, \mathrm{H}-6 \mathrm{a}\right), 2.39$ (m, 0.8H, H-6b for 5), 2.31 (m, 0.2H, H-6b for 6), 1.97 (s, 2.4H, $\mathrm{CH}_{3} \mathrm{CONH}$ for 5), 1.94 (s, 0.6H, $\mathrm{CH}_{3} \mathrm{CONH}$ for 6), $1.58-1.48\left(\mathrm{~m}, 3 \mathrm{H},\left(\mathrm{CH}_{3} \mathrm{CH}_{2} \mathrm{CH}\right)_{\mathrm{x}}\right.$ and $\left(\mathrm{CH}_{3} \mathrm{CH}_{2 a} \mathrm{CH}\right)_{\mathrm{y}}$ of the 3-pentyl moiety), $1.43\left(\mathrm{~m}, 1 \mathrm{H},\left(\mathrm{CH}_{3} \mathrm{CH}_{2 \mathrm{~b}} \mathrm{CH}\right)_{\mathrm{y}}\right.$ of the 3-pentyl moiety), $0.87\left(\mathrm{t}, 3 \mathrm{H}, J=7.5 \mathrm{~Hz},\left(\mathrm{CH}_{3} \mathrm{CH}_{2} \mathrm{CH}\right)_{\mathrm{x}}\right.$ of the 3-pentyl moiety), 0.81 (t, 3H, $J=7.5 \mathrm{~Hz}$, $\left(\mathrm{CH}_{3} \mathrm{CH}_{2} \mathrm{CH}\right)_{\mathrm{y}}$ of the 3-pentyl moiety). ${ }^{13} \mathrm{C}$ NMR $\left(\mathrm{D}_{2} \mathrm{O}\right)$ for compound 5, $\delta 174.7$ (C-1'), 174.2 $\left(\mathrm{CH}_{3} \mathrm{CONH}\right), 169.6\left(\mathrm{CO}_{2} \mathrm{H}\right), 138.4(\mathrm{C}-2), 129.2(\mathrm{C}-1), 103.5\left(\mathrm{C}-1^{\prime}\right), 84.3\left(\mathrm{CH}_{3} \mathrm{CH}_{2} \mathrm{CH}\right.$ of the 3pentyl moiety), 81.0 (C-4'), 76.1 (C-3), 75.3 (C-5”), 72.4 (C-3”, C-2'), 71.0 (C-2”), 70.1 (C-3’), 71.3 and 68.5 (C-4” and C-5’), 61.9 and 61.0 (C-6’ and C-6”), 54.9 (C-4), 47.5 (C-5), 30.0 (C-6), $25.5\left(\left(\mathrm{CH}_{3} \mathrm{CH}_{2} \mathrm{CH}\right)_{\mathrm{x}}\right.$ of the 3-pentyl moiety), $25.1\left(\left(\mathrm{CH}_{3} \mathrm{CH}_{2} \mathrm{CH}\right)_{\mathrm{y}}\right.$ of the 3-pentyl moiety), 22.2 $\left(\mathrm{CH}_{3} \mathrm{CONH}\right), 8.5\left(\mathrm{CH}_{3} \mathrm{CH}_{2} \mathrm{CH}\right.$ of the 3-pentyl moiety).

\section{Acknowledgements}

This work was supported by grants from Agencia Nacional de Promoción Científica y Tecnológica (ANPCyT), National Research Council (CONICET) and Universidad de Buenos 
Aires. R. M. de Lederkremer and R. Agustí are research members of CONICET. We thank A.C.C. Frasch from Universidad Nacional General San Martin, Argentina, for a kind gift of TcTS and Laboratorio Elea SACIFyA for their generous provision of oseltamivir.

\section{References}

1. Moncayo, A. Mem. Inst. Oswaldo. Cruz. 2003, 98, 577.

2. (a) Schenkman, S.; Jiang, M. S.; Hart, G. W.; Nussenzweig, V. Cell 1991, 65, 1117. (b) Frasch, A. C. C. Parasitol. Today 2000, 16, 282. (c) Ferrero-Garcia, M. A.; Trombetta, S. E.; Sanchez, D. O.; Reglero, A.; Frasch, A. C.; Parodi, A. J. Eur. J. Biochem. 1993, 213, 765. (d) Lederkremer, R. M.; Agustí, R. Adv. Carbohydr. Chem. Biochem. 2009, 62, 311.

3. (a) Tomlinson, S.; Pontes de Carvalho, L. C.; Vandekerckhove, F.; Nussenzweig, V. J. Immunol. 1994. 153, 3141. (b) Pereira-Chioccola, V. L.; Acosta-Serrano, A.; Correia de Almeida, I.; Ferguson, M. A.; Souto-Padron, T.; Rodrigues, M. M.; Travassos, L. R.; Schenkman, S. J. Cell Sci. 2000, 113, 1299.

4. Agustí, R.; Giorgi, M. E.; Mendoza, V. M.; Gallo-Rodriguez, C.; Lederkremer R. M. Bioorg. Med. Chem. 2007, 15, 2611.

5. (a) Agusti, R.; Couto, A. S.; Campetella, O. E.; Frasch, A. C. C.; Lederkremer, R. M. Glycobiology 1997, 7, 731. (b) Agusti, R.; Couto, A. S.; Campetella, O.; Frasch, A. C.; Lederkremer, R. M. Mol. Biochem. Parasitol. 1998, 97, 123.

6. (a) Leguizamón, M. S.; Campetella, O. E.; González Cappa, S. M.; Frasch, A. C. Infect. Immun. 1994, 62, 3441. (b) Buscaglia, C. A.; Alfonso, J.; Campetella, O.; Frasch, A. C. Blood 1999, 93, 2025-2032. (c) Alvarez, P.; Buscaglia, C. A.; Campetella, O. J. Biol. Chem. 2004, 279, 3375.

7. (a) Leguizamón, M. S.; Mocetti, E.; Garcia Rivello, H.; Argibay, P.; Campetella, O. J. Infect. Dis. 1999, 180, 1398. (b) Risso, M. G.; Pitcovsky, .T. A.; Caccuri, R. L.; Campetella, O.; Leguizamón, M. S. Parasitology 2007, 134, 503. (c) Mucci, J.; Hidalgo, A.; Mocetti, E.; Argibay, P. F.; Leguizamón, M. S.; Campetella, O. Proc. Natl. Acad. Sci. USA 2002, 99, 3896. (d) Mucci, J.; Mocetti, E.; Leguizamón, M. S.; Campetella, O. J. Immunol. 2005, 174, 4545. (e) Mucci, J.; Risso, M. G.; Leguizamón, M. S.; Frasch, A. C.; Campetella, O. Cell Microbiol. 2006, 8, 1086.

8. Nagamune, K.; Acosta-Serrano, A.; Uemura, H.; Brun, R.; Kunz-Renggli, C.; Maeda, Y.; Ferguson, M. A.; Kinoshita, T. J. Exp. Med. 2004, 199, 1445.

9. (a) Amaya, F. M.; Buschiazzo, A.; Nguyen, T.; Alzari, P. M. J. Mol. Biol. 2003, 325, 773. (b) Buschiazzo, A.; Amaya, M. F.; Cremona, M. L.; Frasch, A. C. C.; Alzari, P. M. Mol. Cell 2002, 10, 757.

10. Damager, I.; Buchini, S.; Amaya, M. F.; Buschiazzo, A.; Alzari, P.; Frasch, A. C.; Watts, A.; Withers, S. G. Biochemistry 2008, 47, 3507. 
11. Scudder, P.; Doom, J. P.; Chenkova, M.; Manger, I. D.; Pereira, M. E. J. Biol. Chem. 1993, 268, 9886.

12. (a) Neres, J.; Bryce, R. J.; Douglas, K. T. Drug Discov. Today 2008, 13, 110. (b) Buchini, S.; Buschiazzo, A.; Withers, S. G. Angew. Chem. Int. Ed. 2008, 47, 2700. (c) Carvalho, S. T.; Sola-Penna, M.; Oliveira, I. A.; Pita, S.; Gonçalves, A. S.; Neves, B. C.; Sousa, F. R.; Freirede-Lima, S.; Kurogochi, M.; Hinou, H.; Nishimura, S.; Mendonça-Previato, L.; Previato, J. O.; Todeschini, A. R. Glycobiology 2010, 20, 1034.

13. (a) Kim, J. H.; Ryu, H. W.; Shim, J. H.; Park, K. H.; Withers, S. G. Chem. Bio. Chem. 2009, 10, 2475. (b) Arioka, S.; Sakagami, M.; Uematsu, R.; Yamaguchi, H.; Togame, H.;

Takemoto, H.; Hinou, H.; Nishimura, S. Bioorg. Med. Chem. 2010, 18, 1633.

14. Agustí, R.; Paris, G.; Ratier, L.; Frasch, A. C. C.; Lederkremer, R. M. Glycobiology 2004, 14, 659.

15. Mucci, J.; Risso, M. G.; Leguizamón, M. S.; Frasch, A. C. C.; Campetella, O. Cell. Microbiol. 2006, 8, 1086.

16. Giorgi, M. E.; Ratier, L.; Agusti, R.; Frasch, A. C. C.; Lederkremer, R. M. Glycoconj. J. 2010, 27, 549.

17. Carvalho, I.; Andrade, P.; Campo, V. L.; Guedes, P. M. M.; Sesti-Costa, R.; Silva, J. S.; Schenkman, S.; Dedola, S.; Hill, L.; Rejzek, M.; Nepogodiev, S. A.; Field, R. A. Bioorg. Med. Chem. 2010, 18, 2412.

18. Busse, H.; Hakoda, M.; Stanley, M.; Streicher, H. J. Carbohydr. Chem. 2007, 26, 159.

19. Paris, G.; Ratier, L.; Amaya, M. F.; Nguyen, T.; Alzari, P. M.; Frasch, A. C. C. J. Mol. Biol. 2005, 345, 923.

20. Buschiazzo, A.; Amaya, M. F.; Cremona, M. L.; Frasch, A. C.; Alzari, P. M. Mol. Cell 2002, 10, 757.

21. (a) Amaya, M. F.; Buschiazzo, A.; Nguyen, T.; Alzari, P. M. J. Mol. Biol. 2003, 325, 773. (b) Watts, A. G.; Oppezzo, P.; Withers, S. G.; Alzari, P. M.; Buschiazzo, A. J. Biol. Chem. 2006, $281,4149$.

22. Demir, O.; Roitberg, A. E. Biochemistry 2009, 48, 3398.

23. Collins, P. J.; Haire, L. F.; Lin, Y. P.; Liu, J.; Russell, R. J.; Walker, P. A.; Skehel, J. J.; Martin, S. R.; Hay, A. J.; Gamblin, S. J. Nature 2008, 453, 1258.

24. Carbain, B.; Martin, S. R.; Collins, P. J.; Hitchcock, P. B.; Streicher, H. Org. Biomol. Chem. 2009, 7, 2570.

25. Veh, R. W.; Michalski, J.; Corfield, A. P.; Sander-Wewer, M.; Gies, D.; Schauer, R. J. Chromatogr. A 1981, 212, 313.

26. Isbell, H. S.; Frush, H. L. Meth. Carbohydr. Chem. 1963, 2, 16. 